\title{
HIGH FREQUENCY TRANSFORMATION OF MUCOR WITH RECOMBINANT PLASMID DNA
}

\author{
by \\ ROBYN VAN HEESWIJCK ${ }^{(1,2)}$ \\ and \\ M. ISABEL G. RONCERO" \\ "Department of Physiology, Carlsberg Laboratory \\ Gamle Carlsberg Vej 10, DK-2500 Copenhagen Valby \\ and \\ ${ }^{2)}$ Christian Hansen's Laboratorium A/S \\ Sankt Annæ Plads 3, DK-1250 Copenhagen K
}

Keywords: Zygomycete, filamentous fungi, gene cloning

\begin{abstract}
Genetic transformation of Mucor circinelloides has been achieved by incubating protoplasts from a leucine requiring strain with recombinant plasmid DNA in the presence of polyethylene glycol and $\mathrm{CaCl}_{2}$. The donor DNA in the initial experiments consisted of pools of recombinant plasmid DNA representing a Mucor genomic library. The library was constncted by insertion of quasi-random fragments of Mucor DNA into the yeast-E. coli shutule vector YRp17. Transformation of Mucor gave rise to Leu prototrophic colonies which were found, by Southern hybridisation analysis, to contain vector DNA sequences. Transformation of $E$. coli with DNA isolated from the Mucor transformants resulted in ampicillin resistant colonies containing plasmid DNA. One of the plasmids, pMCL1302, consisted of YRp17 with an insert of $10.5 \mathrm{~kb}$. It hybridised to Mucor genomic DNA and was capable of complementing the leu mutation. The frequency of transformation obtained with pMCL1302 reached $600 \mathrm{Leu}^{+}$ transformants per $\mu \mathrm{g}$ DNA and $3.2 \times 10^{6}$ viable cells. This is the first report of the cloning of a gene by direct selection in a filamentous fungus, and demonstrates the successful transformation of a fungus of the Class Zygomycetes with plasmid DNA.
\end{abstract}

\section{INTRODUCTION}

The optimal use of recombinant DNA technology in the genetic study of any organism requires the availability of an efficient genetic transformation system. It facilitates the analysis of gene structure, function and regulation, and provides a means for the introduction of novel DNA-sequences into the host genome. Amongst the filamentous fungi, transformation of only three ascomycetous species has been reported using recombinant plasmid DNA. The transformation of Neurospora crassa was accomplished by CASE et al. (10), while the transformation of Podospora anserina and Aspergillus nidulans were first described by STAHL et al. (37) and BALLANCE et al. (3), respectively.

Abbreviations: $\mathrm{bp}=$ base pairs; $\mathrm{kb}=$ kilo base; $\mathrm{EDTA}=$ ethylene diamine tetraacetic acid, sodium salt; $\mathrm{MOPS}=$ 3-(N-Morpholino)propane sulphonic acid; $P E G=$ polyethylene glycol; RNase $A=$ ribonuclease $A ; S D S=$ sodium dodecyl sulphate; $\mathrm{SSC}=$ sodium chloride, sodium citrate buffer; Tris = tris(hydroxymethyl)-aminomethane. 
The ability to obtain transformation at high frequency introduces the possibility of the direct cloning of genes by complementation of mutations with plasmid DNA containing inserts from a genomic library of the wild type strain. This approach has been used in Saccharomyces cerevisiae $(8,22)$, but has not, until now, been applied to the filamentous fungi where the cloning of specific genes has been accomplished by indirect means. The in vitro techniques of cDNA synthesis and hybridisation to oligonucleotide probes have led to the isolation of the glucoamylase cDNA of Aspergillus niger (6) and the am gene of N. crassa (24). The method most often used, however, has involved the screening of genomic libraries for complementation of mutants or expression in Escherichia coli or S. cerevisiae. This approach is limited to those genes which can be expressed in a heterologous organism. Genes cloned by this method are those coding for dehydroquinate lyase (23) and ornithine carbamoyltransferase (5) from A. nidulans, the $\beta$-glucosidase gene from $A$. niger (29), the $\arg 3, \operatorname{trpl}$, and qua2 genes from $\mathrm{N}$. crassa $(9,21,40)$ and a leu gene from Cephalosporium acremonium (15). A DNA fragment from Mucor racemosus (syn. M. circinelloides (32)) has also been reported to complement the leuB6 mutation of $\mathrm{E}$. coli, although this is apparently due to suppression only (12).

The present communication constitutes part of a project designed to establish a transformation system for members of the genus Mucor. Accompanying papers describe the production of stable protoplasts (19) and the isolation of a number of phenotypically different auxotrophic mutants (31) in mesophilic and thermophilic Mucor species. The establishment of a transformation system and thereby introduction of recombinant DNA technology into the genetic study of Mucor was considered desirable for three reasons: (i) Formal genetic analysis of mutants by recombination is not feasible in these fungi due to the difficulties in utilising their sexual cycle. Mating of $(+)$ and $(-)$ strains does not always result in the formation of zygospores, and in some species the numbers produced are low while in others their development is arrested (33). Moreover, the successful germination of zygospores under laboratory conditions is rare and is preceded by a considerable period of dormancy (16). (ii) The study of gene regulation and structure function relationships is of significance to the industrial production of enzymes since Mucor produces a number of extracellular enzymes such as acid proteases $(2,28)$, lipases (35), amylases (1) and cellulases (34). (iii) Mucor provides an ideal system for the study of differential gene expression during the process of morphogenesis, because some species can easily be induced to undergo a morphological change from filamentous to budding yeast-like growth (and vice versa) in response to altered environmental conditions (4).

The results presented in this communication conclusively demonstrate the DNA-mediated transformation of $\mathrm{M}$. circinelloides. In the absence of a cloned and characterised selective marker, we constructed a gene library of wildtype Mucor DNA and selected directly for expression of a gene in Mucor which can transform a leucine requiring strain to prototrophy. The successful complementation of this mutation and subsequent recovery of transformation proficient recombinant plasmids from the Mucor transformant DNA is described. It provides a direct approach to the cloning and identification of genes from filamentous fungi and enables the isolation of genes which are either not expressed in, or have no counterparts in bacteria or yeast.

\section{MATERIALS AND METHODS}

\subsection{Strains}

The wild type strain M. circinelloides $\mathrm{f}$. lusitanicus CBS 277.49 (M. racemosus ATCC 1216b (32)) was used for preparation of donor DNA in the construction of the genomic library (section 2.5). The leucine auxotroph $R 7 B(31)$, a derivative ofCBS 277.49, was the recipient strain in the Mucor transformation experiments (section 2.7).

Escherichia coli HB101 was used for amplification and isolation of plasmid DNA and as the recipient strain in bacterial transformation experiments.

\subsection{Media and growth conditions}

E. coli was grown at $37^{\circ} \mathrm{C}$ in LB medium (25) containing ampicillin $\left(50 \mu \mathrm{g} \cdot \mathrm{ml}^{-1}\right)$ or tetracy- 
cline $\left(25 \mu \mathrm{g} \cdot \mathrm{ml}^{-1}\right)$ as required.

Mucor was grown at $28{ }^{\circ} \mathrm{C}$ in the complete medium YPG (3 g yeast extract, $10 \mathrm{~g}$ peptone and $20 \mathrm{~g}$ glucose per litre distilled $\mathrm{H}_{2} \mathrm{O}$ ) or in the minimal medium YNB (0.5 g Difco yeast nitrogen base without amino acids and ammonium sulphate, $1.5 \mathrm{~g}$ ammonium sulphate, $1.5 \mathrm{~g}$ glutamic acid per litre distilled $\mathrm{H}_{2} \mathrm{O}$ with $1 \%(\mathrm{w} / \mathrm{v})$ glucose added post-sterilisation). The media were adjusted to $\mathrm{pH} 4.5$ with $1 \mathrm{M}-\mathrm{HCl}$ unless restricted colony growth was required (for viability counts, detection of transformants) in which case the media were adjusted to $\mathrm{pH} 3.0 .20 \mathrm{~g} \cdot 1^{-1}$ agar was included for solid media, and in the case of pH 3.0 media, double strength solutions of agar and the other media components were autoclaved separately to avoid acid hydrolysis of the agar.

\subsection{Chemicals}

Restriction enzymes, calf alkaline phosphatase, T4 DNA ligase and E. coli DNA polymerase I were obtained from Boehringer Mannheim (FRG). All enzymes were used according to the conditions specified by the manufacturers. Novozym 234 was a gift from Novo Industries (Denmark), polyethylene glycol (PEG) 4000 was from Fluka AG (Switzerland), heparin, bovine serum albumin (esentially fatty acid free), MOPS, and RNase A were from Sigma (USA), SP Sephadex G50 was from Pharmacia (Sweden), nitrocellulose filters (BA 85) were from Schleicher \& Schuell (FRG), $a^{32} \mathrm{P}$ dATP $(>600 \mathrm{Ci} / \mathrm{mmol})$ was from New England Nuclear (USA).

\subsection{Isolation of DNA}

Preparations of plasmid DNA from small cultures of $\mathrm{E}$. coli were obtained by the rapid boiling method (20). They were treated with RNase A ( $1 \mathrm{mg} \cdot \mathrm{ml}^{-1}$, preheated $90^{\circ} \mathrm{C}, 10 \mathrm{~min}$ ) for one hour at $37{ }^{\circ} \mathrm{C}$ prior to analysis by restriction enzyme digestion and agarose gel electrophoresis. The preparation of plasmids from larger cultures of $\mathrm{E}$. coli followed their amplification overnight in the presence of 150 $\mu \mathrm{g} \cdot \mathrm{ml}^{-1}$ chloramphenicol and was performed according to the method of GORDON and
VAPNEK (17) with minor modifications. The supernatant obtained after high speed centrifugation of the cell lysate was used directly for purification of the DNA by $\mathrm{CsCl}$ gradient centrifugation $\left(\rho=1.55\right.$, containing $0.75 \mathrm{mg} \cdot \mathrm{ml}^{-1}$ ethidium bromide).

The wild-type Mucor DNA used for construction of the genomic library was prepared by a modification of the method described for the isolation of Phycomyces DNA (14). Sporangiospores were inoculated into one litre of YPG pH 4.5 at a density of $10^{5} \cdot \mathrm{ml}^{-1}$ and grown for 16 hours at $28^{\circ} \mathrm{C}$ with shaking. The mycelium was harvested by filtration through nylon cloth (Monodur, mesh size $22 \mu \mathrm{m}$ ) washed with cold distilled $\mathrm{H}_{2} \mathrm{O}$, frozen in liquid nitrogen and ground using a mortar and pestle. The frozen powder was warmed to $0^{\circ} \mathrm{C}$, an equal volume of TE buffer (10mM-Tris, $1 \mathrm{mM}$-EDTA) pH 8.2 was added, and the slurry was filtered through nylon cloth (Monodur, mesh size $10 \mu \mathrm{m}$ ). The solid residue was refrozen, reground, warmed to $0{ }^{\circ} \mathrm{C}$ and combined with the filtrate. The final slurry was brought to $1.5 \%(\mathrm{w} / \mathrm{v})$ SDS and combined with an equal volume of a mixture of phenol (containing $0.1 \%(\mathrm{w} / \mathrm{v})$ 8-hydroxyquinoline and saturated with TE buffer, $\mathrm{pH} 8.2$ ), chloroform and isoamyl alcohol (in the ratios 25:24:1). After shaking at room temperature for five hours, the aqueous phase was obtained by centrifugation (12000 g, $10 \mathrm{~min}$, room temperature), extracted two times with an equal volume of chloroform, isoamyl alcohol (24:1), and then purified by $\mathrm{CsCl}$ gradient centrifugation. The method for obtaining DNA from small cultures of Mucor for the analysis of transformants was derived from that of YELTON et al. (41) for Aspergillus. Cultures were grown from a spore inoculum in $100 \mathrm{ml}$ of YNB pH 4.5 for 20 hours at $28^{\circ} \mathrm{C}$ then the mycelium was harvested and ground as described above. The ground cells were suspended in $10 \mathrm{mls} 50 \mathrm{~mm}$-EDTA pH 8.5, 0.2\% $(w / v)$ SDS and mixed for one minute at room temperature. The lysate was heated at $68^{\circ} \mathrm{C}$ for $15 \mathrm{~min}$, cooled to room temperature and centrifuged ( $12000 \mathrm{~g}, 15 \mathrm{~min}$, room temperature). The supernatant $(10 \mathrm{ml})$ was cooled on ice, $0.6 \mathrm{ml}$ of $8.0 \mathrm{M}$-potassium acetate $\mathrm{pH} 4.2$ was added, and the mixture incubated on ice for $60 \mathrm{~min}$. After centrifugation $\left(25000 \mathrm{~g}, 15 \mathrm{~min}, 4^{\circ} \mathrm{C}\right)$, the 
nucleic acids present in the supernatant were precipitated at room temperature by the addition of an equal volume of isopropanol and collected by centrifugation $(12000 \mathrm{~g}, 30 \mathrm{~min}$, room temperature). The pellet was resuspended in $6.0 \mathrm{ml}$ of TE buffer $\mathrm{pH} 7.6$ and treated with 60 l RNase A $\left(10 \mathrm{mg} \cdot \mathrm{ml}^{-1}\right.$, preheated $90^{\circ} \mathrm{C}, 10$ $\mathrm{min}$ ) for one hour at $37^{\circ} \mathrm{C}$. After extraction with an equal volume of phenol, nucleic acids were precipitated at $-20^{\circ} \mathrm{C}$ after the addition of 0.1 volumes $3.0 \mathrm{M}$-sodium acetate $\mathrm{pH} 4.5$ and 2.5 volumes ethanol. The pellet obtained after centrifugation $\left(12000 \mathrm{~g}, 30 \mathrm{~min}, 4^{\circ} \mathrm{C}\right)$ was resuspended in $500 \mu \mathrm{l}$ TE buffer, $\mathrm{pH} 8.0$ and the DNA content estimated by agarose gel electrophoresis. The DNA prepared in this manner was not always susceptible to digestion by restriction endonucleases, so an extra purification step of $\mathrm{CsCl}$ gradient centrifugation was sometimes included.

\subsection{Construction of a genomic library from Mucor}

The plasmid used was the yeast-E. coli shuttle vector YRp17 (Figure 1), kindly supplied by $\mathbf{M}$. MCDONELL. It carries the TRPI and URA3 genes for selection in yeast, and genes conferring resistance to ampicillin and tetracycline in $E$. coli (7). YRp17 was linearised with Bam HI, treated with calf alkaline phosphatase to prevent recircularisation, and then mixed with an equal amount of Mucor DNA that had been partially digested with Mbo I to produce an average fragment size of $10 \mathrm{~kb}$. After treatment with $\mathrm{T} 4$ DNA ligase for 16 hours at $12{ }^{\circ} \mathrm{C}$, the resulting ligation mixture was used to transform $\mathrm{E}$. coli HB101 to ampicillin resistance. Among the transformants obtained, $93 \%$ were tetracycline sensitive, indicating that their plasmids contained Mucor DNA inserts. A total of 60,000 transformants were divided into groups containing approximately 2,000 colonies each, amplified overnight by growth in one litre media, and used to prepare 30 independent pools of recombinant plasmid DNA. Aliquots of the plasmid pools obtained were digested with Bam HI and electrophoresed in agarose gels $0.7 \%$ $(w / v))$ in order to assess the size of the Mucor DNA inserts (Figure 2).

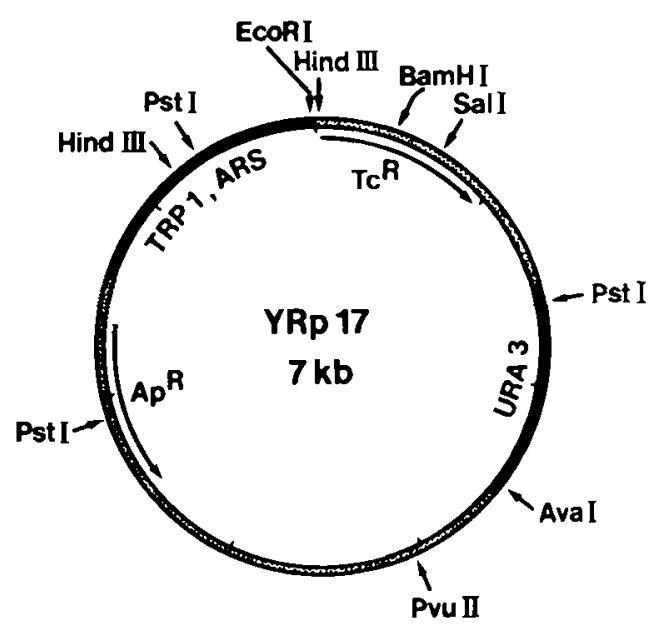

Figure 1. Restriction map of the yeast-E. coli shuttle vector YRp 17. Location of restriction sites: Ava I, Bam HI, Eco RI, Hind III, Pst I, Pvu II and Sal I are shown. The thick black line corresponds to the TRPI and $U R A 3$ genes and to the origin of replication $(A R S)$ from $S$. cerevisiae. The stippled line is pBR322.

\subsection{Transformation of $\mathbf{E}$. coli}

E. coli HB101 was transformed to ampicillin resistance after induction of cell competence by the $\mathrm{CaCl}_{2}$ method (26).

\subsection{Transformation of Mucor}

Sporangiospores of $\mathrm{M}$. circinelloides R7B were suspended in $150 \mathrm{ml}$ YPG pH 4.5 at a concentration of $10^{7} \cdot \mathrm{ml}^{-1}$ and germinated for 3-5 hours at $28^{\circ} \mathrm{C}$ with shaking. The germlings were harvested by filtration through nylon cloth (Monodur, $22 \mu \mathrm{m}$ ) washed extensively with 0.01 M-sodium phosphate buffer pH 6.5 , then incubated in the same buffer containing $0.5 \mathrm{M}$-sorbitol, $1.5 \mathrm{mg} \cdot \mathrm{ml}^{-1}$ Novozym 234 and $0.5 \mathrm{mg} \cdot \mathrm{ml}^{-1}$ streptozyme (19), for $2-3$ hours at $23^{\circ} \mathrm{C}$. A more detailed description of the formation of protoplasts is given in an accompanying paper (19). The protoplasts and any undigested cells remaining were pelleted by centrifugation (400 $\mathrm{g}, 5 \mathrm{~min}$, room temperature) washed twice with $0.5 \mathrm{M}$-sorbitol, once with $0.5 \mathrm{M}$-sorbitol in MOPS buffer (10 mM-MOPS pH 6.3, $50 \mathrm{~mm}$ $\mathrm{CaCl}_{2}$ ), then resuspended in the same solution to give a final volume of $2 \mathrm{ml}$. Aliquots of $0.2 \mathrm{ml}$ 


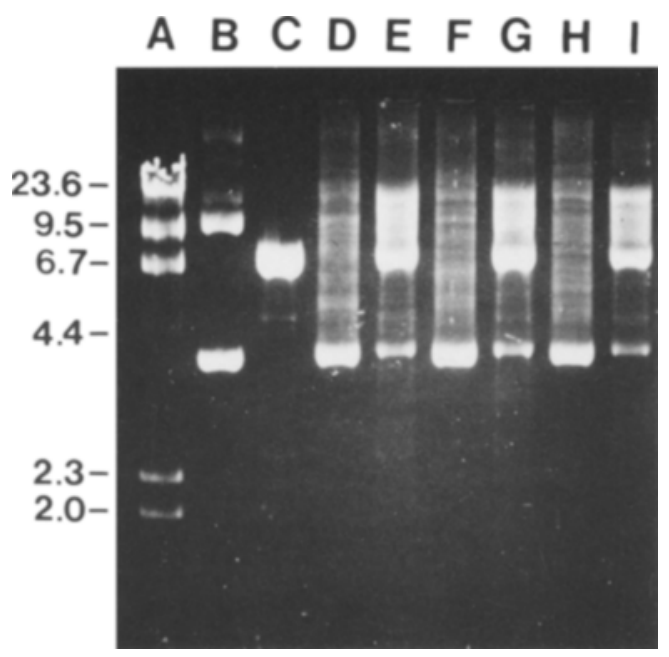

Figure 2. Agarose gel electrophoresis of DNA from YRp 17 and three different plasmid pools. Lane A: Phage $\lambda$ DNA Hind III fragments, used as size markers (kb). Lanes B, D, F, and H: undigested DNA from YRp17 and from pools no. 1, 2, and 3, respectively. Lanes C, E, G, and I: Bam HI digestion of DNA from YRp17 and from pools 1, 2, and 3, respectively.

were added to $20 \mu$ l of the plasmid DNA $(0.1$ $50 \mu \mathrm{g}$, pretreated with $1 \mathrm{mg}$ heparin in 0.5 M-sorbitol, MOPS buffer for $20 \mathrm{~min}$ on ice) plus $20 \mu 140 \%$ (w/v) PEG 4000 in MOPS buffer (11). After incubation on ice for $30 \mathrm{~min}, 2.5 \mathrm{ml} 40 \%$ (w/v) PEG 4000 in MOPS buffer was added and the incubation continued at room temperature for $25 \mathrm{~min}$. The suspensions were diluted with 20 $\mathrm{ml} 0.5 \mathrm{M}$-sorbitol in MOPS buffer, centrifuged ( $400 \mathrm{~g}, 5 \mathrm{~min}$, room temperature) and the pellet resuspended in $5 \mathrm{ml} \mathrm{YPG} \mathrm{pH} \mathrm{4.5,0.5} \mathrm{M-sorbitol.}$ After $30 \mathrm{~min}$ incubation at room temperature the cells were centrifuged $(400 \mathrm{~g}, 5 \mathrm{~min}$, room temperature), then resuspended in $5 \mathrm{ml}$ of YNB $\mathrm{pH} 4.5,0.5 \mathrm{M}$-sorbitol and $1 \mathrm{ml}$ aliquots were plated in soft agar overlays $(9 \mathrm{ml}$ of $\mathrm{YNB}$ pH 3.0, $0.5 \mathrm{M}$-sorbitol, $1 \%(\mathrm{w} / \mathrm{v}$ ) agar) onto YNB pH 3.0, $0.5 \mathrm{M}$-sorbitol agar plates. Assessment of the number of potential colony forming units was made by plating diluted aliquots onto YPG $\mathbf{p H}$ 3.0, $0.5 \mathrm{M}$-sorbitol. Plates were incubated at room temperature for 2-3 days before colonies were counted.

\subsection{Hybridisation analysis}

DNA fragments generated after restriction endonuclease treatment were electrophoretically separated on $0.7 \%(\mathrm{w} / \mathrm{v})$ agarose gels, then transferred to nitrocellulose filters according to the method of SOUTHERN (36). Plasmid DNA was labelled in vitro with $\alpha^{32} \mathrm{P}$-dATP by nick translation according to RIGBY et al. (30). Specific radioactivities of $3-4 \cdot 10^{7} \mathrm{cpm}$ per $\mu \mathrm{g}$ DNA were obtained. Hybridisation of ${ }^{32}$ P-labelled plasmid DNA to the DNA immobilised on nitrocellulose was performed at $68^{\circ} \mathrm{C}$ in $6 \times \mathrm{SSC}$ according to MANIATIS et al. (27). Autoradiography was carried out using Kodak X-Omat RP $\mathrm{X}$-ray film with Kodak $\mathrm{X}$-Omatic regular intensifying screens at $-80^{\circ} \mathrm{C}$.

\section{RESULTS}

\subsection{Transformation of Mucor with recombinant plasmid pools}

M. circinelloides R7B Leu (31) was used as the recipient in all transformation experiments. The spontaneous reversion frequency of this strain to $\mathrm{Leu}^{+}$is $<1.7 \cdot 10^{-8}$. The transformation of this strain by wild-type DNA should, by complementation of the mutant allele, produce a Leu phenotype. The DNA used in the initial transformation experiments came from pools of amplified recombinant plasmids which constitute a genomic library of wild-type $M$. circinelloides (section 2.5 ). Approximately $2 \times 10^{6}$ viable protoplasts of strain $\mathrm{R} 7 \mathrm{~B}$ were incubated with $10-50 \mu \mathrm{g}$ of recombinant plasmid DNA in the presence of $\mathrm{PEG}$ and $\mathrm{CaCl}_{2}$ as described in section 2.7 then plated onto minimal media. After two days at room temperature prototrophic colonies appeared which were capable of sporulation and which could be transferred to fresh minimal media with continued growth. No prototrophic colonies were obtained in parallel transformation experiments where either the DNA was omitted, or replaced by $25 \mu \mathrm{g}$ of YRp17. Out of the 10 different recombinant plasmid pools tested, a total of four gave rise to $\mathrm{Leu}^{+}$colonies. The number of colonies obtained varied from pool to pool but was within the range of 1-38. 

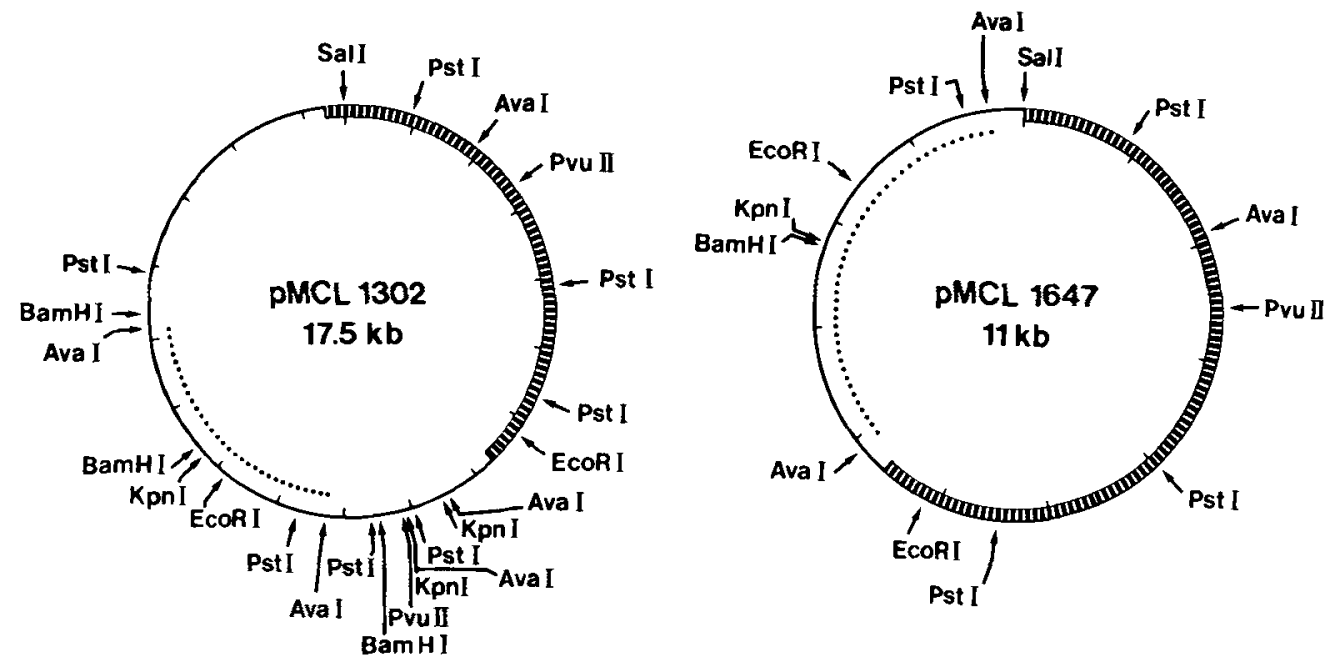

Figure 3. Restriction maps of plasmids pMCL1302 and pMCL1647. Plasmids are not drawn to the same scale. Location of restriction sites: Ava I, Bam HI, Eco RI, Kpn I, Pst I, Pvu II and Sal I are shown. The thick line is the vector YRp17 and the thin line is the Mucor DNA insert. The dotted line indicates the region of homology between the inserts.

\subsection{Recovery of plasmids from Mucor transformants}

Strong evidence that the $\mathrm{Leu}^{+}$phenotype was due to plasmid-mediated complementation of the original mutation and not to spontaneous reversion was provided by the recovery of recombinant plasmids from the DNA of Mucor transformants.

Total DNA from 19 different $\mathrm{Leu}^{+}$Mucor transformants, grown in minimal medium, was treated with Kpn I, self-ligated and used in the transformation of E. coli HB101. Although the DNA appeared undigested after the Kpn I treatment (it had not been purified by $\mathrm{CsCl}$ gradient centrifugation, see section 2.4) one ampicillin resistant colony was obtained. The plasmid recovered from this transformant was designated pMCL1302.

In an attempt to increase the number of bacterial transformants obtained, the Mucor DNA was purified by $\mathrm{CsCl}$ gradient centrifugation. DNA from five Leu ${ }^{+}$transformants was then successfully digested with Sal I, self-ligated and used to transform E. coli. In this way, four ampicillin resistant colonies were obtained from two different DNA preparations. The plasmid recovered from one of these was designated pMCL1647.
Physical maps of plasmids pMCL1302 and pMCL1647 were obtained by single and double digestions with seven restriction enzymes (Figure 3). They consist of YRp17 with Mucor DNA inserts of $10.5 \mathrm{~kb}$ and $4.0 \mathrm{~kb}$, respectively. The inserts in the two plasmids have a homologous region of $3.7 \mathrm{~Kb}$ delimited by two Ava I restriction sites, but placed in opposite orientation relative to the YRp17 sequences. They originate from Mucor colonies transformed to $\mathrm{Leu}^{+}$with recombinant plasmid from pools no. 13 and no. 16, respectively, and are in themselves capable of transforming $M$. circinelloides R7B to $\mathrm{Leu}^{+}$(section 3.4).

Plasmid pMCL1647 is smaller than the original transforming plasmid from pool no. 16. The size of the latter can be estimated to be at least $16.9 \mathrm{~kb}$ from Figure 4, lane $\mathrm{H}$, since ${ }^{32} \mathrm{P}$-labelled YRp1 7 hybridises to four Pst I fragments with sizes of $1.5,3.2,5.2$ and $7 \mathrm{~kb}$. Three of these fragments are found in pMCL1647 (Figure 3) but the $7 \mathrm{~kb}$ fragment is absent being replaced by one of $1.4 \mathrm{~kb}$. A Sal I site must thus have been located within the original transforming plasmid between the Sal I site in the $\mathrm{Tc}^{\mathrm{R}}$ gene and the proximal Ava I site of the insert. The Sal I digestion of the Leu ${ }^{+}$Mucor DNA prior to E. coli transformation thus deleted the 5.6 
$\mathrm{kb}$ fragment and resulted in recovery of pMCL1647.

The low number of $\mathrm{E}$. coli transformants obtained above is not necessarily a measure of the abundance of the plasmid within the Mucor DNA. In reconstruction experiments where YRp17 was mixed with Mucor DNA that had, or had not been purified by $\mathrm{CsCl}$ gradient centrifugation, the frequency of E. coli transformation was found to be reduced to $16 \%$ and $.03 \%$, respectively, when compared with that obtained using YRp17 alone.

\subsection{Hybridisation analysis of transformant DNA}

Further confirmation that the $\mathrm{Leu}^{+}$colonies described in section 3.1 were transformants was provided by the detection of YRp17 plasmid sequences within their DNA. Total DNA was isolated from a number of transformants and purified by $\mathrm{CsCl}$ gradient centrifugation. The fragments obtained after digestion with Bam HI or Pst I were separated by agarose gel electrophoresis, transferred to nitrocellulose filters and hybridised to ${ }^{32} \mathrm{P}$-labelled YRp17. All 22 transformants so far examined showed specific hybridisation to YRp17 whilst DNA isolated from the recipient strain $\mathrm{R} 7 \mathrm{~B}$ contained no sequences complementary to this probe. The hybridisation patterns obtained were of two types and representative autoradiographs are shown in Figure 4. The patterns shown for transformant 1302 are representative of all five transformants so far examined which originate from plasmid pool no. 13. Similarly, those shown for 1611 are representative of all 14 transformants so far examined which originate from plasmid pool no. 16. While the $3.2 \mathrm{~kb}$ and $1.5 \mathrm{~kb}$ Pst I fragments of YRp17 are present in all transformants, the $2.3 \mathrm{~kb}$ Pst I fragment which contained the Bam HI cloning site (section 2.5) has been replaced by two, more weakly hybridising fragments, indicating the presence of an insert with at least one internal Pst I site. After Bam HI digestion a single hybridising fragment is obtained in all transformants. These fragments are larger than linear YRp17 indicating again the presence of inserts within the plasmid DNA. The insertion of Mbo I digested DNA into the

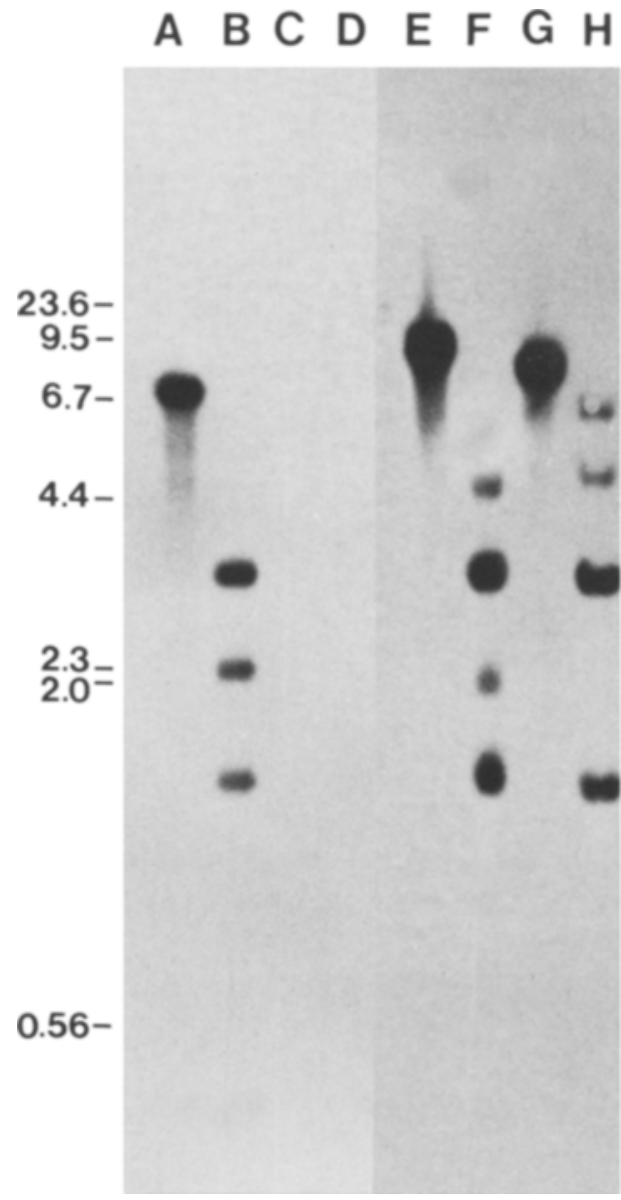

Figure 4. Southern hybridisation of ${ }^{32} \mathrm{P}$-labelled YRp1 7 plasmid DNA to $M$. circinelloides DNA. DNA $(2 \mu \mathrm{g})$ from untransformed and transformed M. circinelloides R7B was cleaved with Bam HI or Pst I, electrophoresed in a $0.7 \%$ agarose gel and transferred to nitrocellulose paper. The DNA was then hybridised with ${ }^{32} \mathrm{P}$-labelled YRp17. Lanes contain DNA from the following sources: $A$ and $B, Y R p 17(1 \mathrm{ng}) ; C$ and $D$, recipient strain $R 7 B ; E$ and $F$, transformant $R 7 B-$ 1302; $G$ and $H$, transformant R7B-1611. Lanes $A$, $C, E$ and $G$ contain Bam HI digested DNA, lanes B, D, F and $\mathrm{H}$ contain Pst I digested DNA. All samples are run on the same gel but lanes A-D were exposed for 8 hours at $-80^{\circ} \mathrm{C}$, while lanes $\mathrm{E}-\mathrm{H}$ were exposed for 15 hours at $-80^{\circ} \mathrm{C}$.

Bam HI site of a plasmid rarely regenerates Bam $\mathrm{HI}$ sites at the points of re-ligation.

The hybridisation of ${ }^{32} \mathrm{P}$-labelled pMCL1302 to Bam HI and Pst I digests of DNA from the 


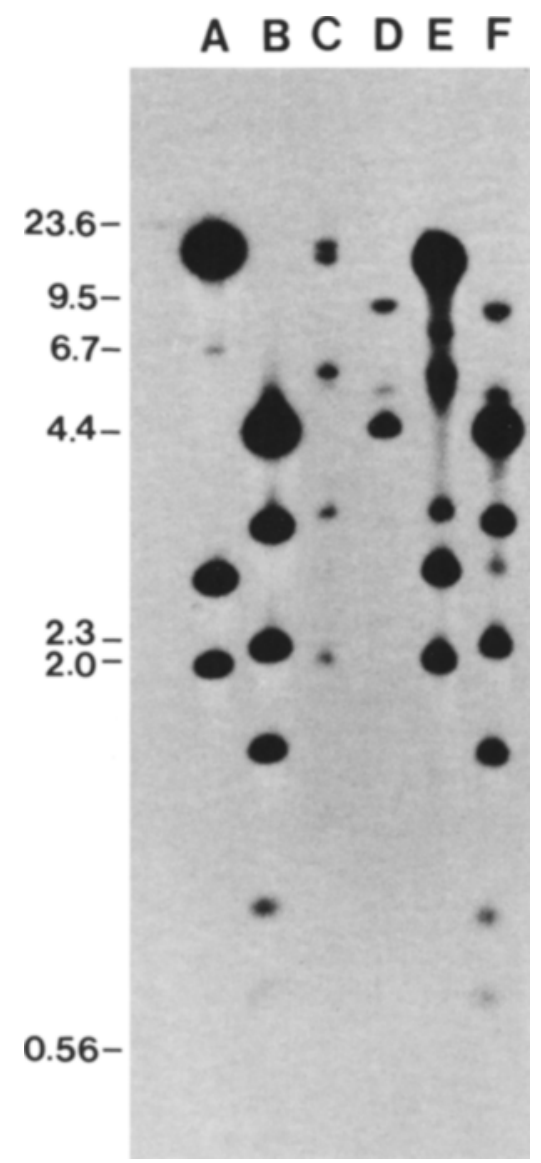

Figure 5. Southern hybridisation of ${ }^{32} \mathrm{P}$-labelled pMCL 1302 plasmid DNA to M. circinelloides DNA. DNA $(2 \mu \mathrm{g})$ from untransformed and transformed $M$. circinelloides R7B was cleaved with Bam HI or Pst I, electrophoresed in a $0.7 \%$ agarose gel and transferred to nitrocellulose paper. The DNA was then hybridised with ${ }^{32}$ P-labelled pMCL1302. Lanes contain DNA from the following sources: A and B, pMCL1302 (1 $\mathrm{ng}$ ); $\mathrm{C}$ and $\mathrm{D}$, recipient strain $\mathrm{R} 7 \mathrm{~B}$; $\mathrm{E}$ and $\mathrm{F}$, transformant R7B-1302. Lanes $A, C$ and $E$ contain Bam HI digested DNA, lanes B, D and F contain Pst I digested DNA. Autoradiographic exposure was for 15 hours at $-80{ }^{\circ} \mathrm{C}$.

untransformed strain R7B and from the $\mathrm{Leu}^{+}$ transformant 1302 is shown in Figure 5. Since the DNA from strain R7B shares no homology with YRp17 (Figure 4), the bands in lanes C and $\mathrm{D}$ represent hybridisation of Mucor genomic DNA to the insert alone of pMCL1302. By restriction map analysis this insert has been determined to contain 3 Bam $\mathrm{HI}$ sites and 4 Pst I sites (Figure 3). Thus the patterns obtained in lanes $C$ and $D$ suggest its structure to be more complex than if it were simply a contiguous piece of chromosomal DNA devoid of repetitive DNA sequences. Both the $2.1 \mathrm{~kb}$ Bam HI fragment and the $4.7 \mathrm{~kb}$ Pst I fragment contained within the insert are found intact in the genomic DNA, but neither the $2.9 \mathrm{~kb}$ Bam HI fragment nor the $0.95 \mathrm{~kb}$ and $0.7 \mathrm{~kb}$ Pst I fragments can be detected. Lack of detection of the latter two fragments may be due to their small size resulting in very faint bands upon radioautography. However, the absence of the $2.9 \mathrm{~kb}$ fragment from the Bam HI digested genomic DNA, combined with the detection of five relatively strong bands suggests that the insert was created by the ligation of two different Mbo I fragments during construction of the genomic library. Location of the point of ligation within the 2.9 $\mathrm{kb}$ Bam HI fragment would explain its absence from the genomic DNA. Further evidence for this is provided by an apparent discontinuity in the otherwise almost complete homology of the inserts of plasmids pMCL1302 and pMCL1647 (Figure 3). If the inserts were completely homologous one should expect to find a Sal I site within the $2.9 \mathrm{~kb}$ Bam HI fragment of pMCL1302 (section 3.2).

The hybridisation of pMCL1 302 to the DNA from the $\mathrm{Leu}^{+}$transformant 1302 results in patterns (lanes $\mathrm{E}$ and $\mathrm{F}$ ) consisting of strong bands corresponding to the plasmid DNA derived sequences (lanes $A$ and $B$ ) plus slightly weaker bands corresponding to the genomic DNA sequences present in the recipient strain (lanes $C$ and D). These patterns are consistent either with integration of the transforming DNA into a homologous region(s) of the chromosome(s) and/or the existence of free plasmid molecules. Further analyses are under way to determine more precisely the fate of the plasmid DNA within the cell.

\subsection{Transformation of Mucor with pMCL1302 and pMCL1647}

The frequency of transformation of strain R7B to $\mathrm{Leu}^{+}$using the plasmid pMCL1302 is shown in Table I. Both the concentration of 
Table 1

Transformation of M. circinelloides R7B to Leu* with pMCL1302"

\begin{tabular}{|c|c|c|c|c|c|}
\hline \multirow{2}{*}{ Experiment } & \multirow{2}{*}{$\begin{array}{l}\text { DNA } \\
\mu \mathrm{g}\end{array}$} & \multirow{2}{*}{$\begin{array}{l}\text { no. viable } \\
\text { cells plated }\end{array}$} & \multirow{2}{*}{$\begin{array}{l}\text { no. Leu } \\
\text { colonies }\end{array}$} & \multicolumn{2}{|c|}{ transformation frequency } \\
\hline & & & & per $\mu \mathrm{g}$ DNA & per viable cell \\
\hline \multirow[t]{4}{*}{1} & 0 & $2.9 \times 10^{7}$ & 0 & 0 & 0 \\
\hline & 0.1 & $2.9 \times 10^{7}$ & 72 & 720 & $2.5 \times 10^{.6}$ \\
\hline & 0.5 & $2.9 \times 10^{7}$ & 120 & 240 & $4.1 \times 10^{-5}$ \\
\hline & 1.0 & $2.9 \times 10^{7}$ & 216 & 216 & $7.4 \times 10^{-6}$ \\
\hline \multirow[t]{2}{*}{2} & 0 & $3.2 \times 10^{6}$ & 0 & 0 & 0 \\
\hline & 1.0 & $3.2 \times 10^{6}$ & 600 & 600 & $1.9 \times 10^{.4}$ \\
\hline \multirow[t]{4}{*}{3} & 0 & $5 \times 10^{5}$ & 0 & 0 & 0 \\
\hline & 1.0 & $5 \times 10^{5}$ & 193 & 193 & $3.9 \times 10^{-4}$ \\
\hline & 5.0 & $5 \times 10^{5}$ & 234 & 47 & $4.7 \times 10^{-4}$ \\
\hline & 25.0 & $5 \times 10^{5}$ & 473 & 19 & $9.5 \times 10^{-4}$ \\
\hline
\end{tabular}

"Transformation was carried out as described in section 2.7 using the amount of DNA shown above. The colonies counted were all vigorously growing, sporulating, and capable of growth upon transfer to fresh minimal media.

DNA and the density of cells plated were found to have an influence on the number of $\mathrm{Leu}^{+}$ colonies obtained. Up to 720 transformants per $\mu \mathrm{g}$ DNA were obtained using 0.1-1.0 $\mu \mathrm{g}$ plasmid DNA. An increase in the amount of DNA used gave an increase in the number of transformants but the frequency of transformation (per $\mu \mathrm{g}$ DNA) progressively decreased. This indicates that DNA concentration was not the sole limiting factor. In terms of the number of viable cells plated the transformation frequency varied from $2.5 \times 10^{-6}$ to $9.5 \times 10^{-4}$. The relatively low frequency obtained at the highest plating density probably reflects inhibition of the growth of the transformed cells by the non-transformed cells $(11,18)$.

Treatment of strain R7B with pMCL1647 also gave rise to Leu ${ }^{+}$colonies but the frequency of transformation was much lower than that obtained using pMCL1302. In an experiment conducted concurrently with experiment 1 of Table I, $1.0 \mu \mathrm{g}$ and $5.0 \mu \mathrm{g}$ of pMCL1647 gave rise to 6 and 17 stable $\mathrm{Leu}^{+}$colonies, respectively. An equivalent number of very small colonies which could not grow upon transfer to fresh minimal media were obtained. These resemble the "abortive" transformants described previously in N. crassa (11) and A. nidulans (39). The reasons for the lower transformation frequency with pMCL 1647, and for the abortive growth pattern are not presently known.

\section{DISCUSSION}

The results described in this paper unequivocally demonstrate the transformation of Mucor with plasmid DNA and represent the first instance of the transformation of a fungus of the Class Zygomycetes. The frequency of transformation obtained (600 $\mathrm{Leu}^{+}$transformants per $\mu \mathrm{g}$ pMCL1 302 and $3.2 \times 10^{6}$ viable cells) is relatively high when compared with the plasmidmediated transformation of other filamentous fungi, although a precise comparison is difficult to make because of the wide range of frequencies reported and because abortive transformants are often included.

The high frequency of transformation obtained made possible the direct selection of a Mucor gene by complementation of a $\mathrm{Leu}^{-}$ auxotroph with recombinant plasmid DNA from a genomic library. The subsequent recovery of the transformation proficient plasmids pMCL1302 and pMCL1647 has provided an enriched source of the DNA able to complement the $\mathrm{Leu}^{-}$auxotrophic mutant. Using the same approach it should be possible to identify by complementation virtually any Mucor gene for 
which appropriate defective mutants can be obtained. The haploid genome size of Mucor has been estimated by reassociation kinetics to be approximately $10^{\prime} \mathrm{bp}(38)$. Any gene present as a single copy sequence should be represented with a probability of $99 \%$ in a genomic library of only $5 \times 10^{3}$ clones when the average fragment size is $10 \mathrm{~kb}(13)$. This is consistent with our results (section 3.1) where upon screening ten recombinant plasmid pools (representing $2 \times 10^{4}$ independently derived clones) four gave rise to $\mathrm{Leu}^{+}$colonies. This number of pools can easily be screened in a single experiment.

The inserts of plasmids pMCL1302 and pMCL1647 are homologous within a region of at least $3.7 \mathrm{~kb}$ (delimited by two Ava I sites) as determined by restriction enzyme analysis and both are capable of transforming strain R7B to Leu+. Experiments to locate the complementing DNA fragment more precisely are at present under way and the DNA sequence will be determined. It is possible that the plasmids carry a gene that is capable of suppressing the mutant allele of strain R7B. A fragment of genomic DNA from $M$. racemosus(syn. $M$. circinelloides (32)) has been reported to be capable of suppressing the leuB6 allele of E. coli (12). In attempts to transform E. coli strains carrying the leuB6 allele we found that neither pMCL1302 nor pMCL1647 are able to complement this mutation and we presume, therefore, that this earlier isolated fragment and the fragments we have isolated are not the same. Both pMCL1302 and pMCL1647 also fail to complement a S. cerevisiae strain carrying a mutation in the leu2 gene. The Mucor gene carried by these plasmids presumably codes for an enzyme other than $\beta$-isopropylmalate dehydrogenase, although the lack of complementation may also be explained by its inability to be efficiently expressed.

The fate of the transforming DNA within the Mucor cell is not yet clear. The hybridisation analyses carried out (Figure 4 and Figure 5) do not discriminate between integration of the plasmid at homologous region(s) of the chromosome(s), or its existence as a self-replicating entity, or the simultaneous occurrence of both events. From Figure 5 a comparison of the strength of the hybridisation bands between the untransformed recipient strain R7B and the transformed strain 1302 suggests the presence of more than one copy of the transforming DNA per genome. The recovery of plasmid pMCL1302 from Kpn I treated, but apparently undigested DNA (section 3.2) suggested the existence of free plasmid within the Mucor transformants. Subsequent transformation of $\mathrm{E}$. coli with undigested DNA purified by $\mathrm{CsCl}$ gradient centrifugation (section 2.4) has resulted in a number of ampicillin resistant colonies whose plasmids are now being analysed. It is of interest to note here that of the 22 Mucor transformants so far examined, all contain sequences homologous to the vector DNA, YRp17. In $N$. crassa only $25 \%$ of the transformants contain vector sequences (11) while in A. nidulans the frequency ranges from $80 \%(41)$ to $100 \%$ (39); in all cases transformation was shown to occur by integration.

\section{ACKNOWLEDGEMENTS}

We are indebted to Julio Polaina for his advice concerning the construction of the genomic library. STEEN Holmberg and DAVID SIMPSON are thanked for their helpful discussions and critical reading of the manuscript. We acknowledge the excellent technical assistance of Mona Elster and ANETte JørGensen, and the help of NINA RASMUSSEN and ANNSOFI STEINHOLz in the preparation of the figures. We are grateful for the continuous moral support provided by Professor DITER VON WETTSTEIN. M.I.G. RONCERO had a postdoctoral fellowship from Ministerio de Educación y Ciencia (Spain).

\section{REFERENCES}

1. ADAMS, P.R. \& J.J. DePloEY: Amylase production by Mucor miehei and Mucor pusillus. Mycologia 68, 934-938 (1976)

2. Arima, K., S. Iwasaki \& G. Tamura: Milk-clotting enzyme from microorganisms. V. Purification and crystallization of Mucor rennin from Mucor pusillus var. Lindt. Appl. Microbiol. 16, 1727 1733 (1968)

3. Ballance, D.J., F.P. Buxton \& G. Turner: Transformation of Aspergillus nidulans by the orotidine-5'-phosphate decarboxylase gene of 
Neurospora crassa. Biochem. Biophys. Res. Commun. 112, 284-289 (1983)

4. BartNicki-Garcia, S: Symposium on biochemical bases of morphogenesis in fungi. III. Moldyeast dimorphism of Mucor. Bacteriol. Rev. 27, 293-304 (1963)

5. Berse, B., A. DMOChOWSKA, M. SKRZYPEK. P. Weglenski, M.A. Bates \& R.L. Weiss: Cloning and characterization of the ornithine carbamoyltransferase gene from Aspergillus nidulans. Gene $25,109-117$ (1983)

6. Boel, E., I. HJort, B. Svensson, F. NORRIS, K.E. NORRIS \& N.P. FIIL: Glucoamylases G1 and G2 from Aspergillus niger are synthesized from two different but closely related mRNAs. EMBO J, 3, 1097-1102 (1984)

7. Botstein, D. \& R.W. Davis: Principles and practice of recombinant DNA research with yeast. In: The Molecular Biology of the yeast Saccharomyces cerevisiae. J.N. Strathern, E.W. Jones and J.R. Broach eds. Cold Spring Harbor, New York, vol. J B, pp. 607-636 (1982)

8. BRoACH, J.R., J.N. STRATHERN \& J.B. HiCkS: Transformation in yeast: Development of a hybrid cloning vector and isolation of the $C A N 1$ gene. Gene, 8, 121-133 (1979)

9. BUXTON,F.P.\&A. RADFORD: Cloning of the structural gene for orotidine 5'-phosphate carboxylase of Neurospora crassa by expression in Escherichia coli. Mol. Gen. Genet., 190, 403-405 (1983)

10. Case M.E., M. SCHWeizer, S.R. Kushner \& N.H. GiLes: Efficient transformation of Neurospora crassa by utilizing hybrid plasmid DNA. Proc. Natl. Acad. Sci. USA, 76, 5259-5263 (1979)

11. CASE M.E.: Transformation of Neurospora crassa utilising recombinant plasmid DNA. In: Genetic engineering of microorganisms for chemicals. A. Hollaender, R.D. DeMoss, S. Kaplan, J. Konisky, D. Savage and R.S. Wolfe, eds. Plenum Press. N. Y., pp. 87-100 (1982)

12. Cihlar, R.L. \& P.S. SYPherd: Complementation of the leuB6 allele of Escherichia coli by cloned DNA from Mucor racemosus. J. Bacteriol. 151, $521-523$ (1982)

13. Clarke, L \& J Carbon: A colony bank containing synthetic Col El hybrid plasmids representative of the entire E. coli genome. Cell 9, 91-99 (1976)

14. DUSENBERY, R.L.: Characterization of the genome of Phycomyces blakesleeanus. Biochim. Biophys. Acta 378, 363-377 (1975)

15. Friedlin, E. \& J. NÜESCH: Isolation of a selective marker from Cephalosporium acremonium by complementation of an auxotrophic mutant of $E$. coli. Current Genet. 8, 271-276 (1984)

16. Gauger, W:: The germination of zygospores of
Mucor hiemalis. Mycologia 57, 634-641 (1965)

17. Gordon, G.N. \& D. VAPNEK: A simple method of preparing large amounts of $\$ F X 174$ RFI supercoiled DNA. Biochim. Biophys. Acta 299, 516520, (1973)

18. GrigG, G.W: Competitive suppression and the detection of mutations in microbial populations. Aust. J. Biol. Sci., 11, 69-84 (1958)

19. HeEswiJCK, R. van: The formation of protoplasts from Mucor species. Carlsberg Res. Commun. 49, $597-609$ (1984)

20. Holmes, P.S. \& M. Quigley: A rapid boiling method for the preparation of bacterial plasmids. Anal. Biochem. 114, 193-197 (1981)

21. KeESEY, J.K.JR. \& J.A. DemosS: Cloning of the trp-I gene from Neurospora crassa by complementation of a $\operatorname{trp} C$ mutation in Escherichia coli. J. Bacteriol. 152, 954-958 (1982)

22. KIELLAND-BRANDT, M.C., T.NILSSON-TILLGREN, S. Holmberg, J.G. LitSKe PETERSEN \& B.A. SVENNINGSEN: Transformation of yeast without the use of foreign DNA. Carlsberg Res. Commun. 44, 77-87 (1979)

23. KINGHORN, J.R. \& A.R. HAWKINS: Cloning and expression in Escherichia coli K-12 of the biosynthetic dehydrogenase function of the arom cluster gene from the eucaryote, Aspergillus nidulans. Mol. Gen. Genet. 186, 145-152 (1982)

24. Kinnaird, J.H., M.A. Kelghern, J.A. Kinsey, M. EATON \& J.R.S. FINCHAM: Cloning of the am (glutamate dehydrogenase) gene of Neurospora crassa through the use of a synthetic DNA probe. Gene 20, 387-396 (1982)

25. LeNNOX, E.S.: Transduction of linked genetic characters of the host by bacteriophage P1. Virology 1, 190-206 (1955)

26. Mandel, M. \& A. Higa: Calcium-dependent bacteriophage DNA infection. J. Mol. Biol. 53, 159162 (1970)

27. MANIATIS, T., E.F. FRITSCH \& J. SaMbroOK: Molecular cloning, a laboratory manual. Cold Spring Harbor, New York, 1982

28. OtTesen, M. \& W. Rickert: The isolation and partial characterisation of an acid protease produced by Mucor miehei. Compt. Rend. Trav. Lab. Carlsberg. 37, 301-325 (1970)

29. Penttilä, M.E., K.M.H. Nevalainen, A RaYNAL \& J.K.C. KNowles: Cloning of Aspergillus niger genes in yeast. Expression of the gene coding Aspergillus $\beta$-glucosidase. Mol. Gen. Genet. 194, 494-499 (1984)

30. Rigby, P.W.J., M. DieckmanN, C. Rhodes \& P BERG: Labeling deoxyribonucleic acid to high specific activity in vitro by nick translation with DNA polymerase I. J. Mol. Biol. 113, 237-251 
(1977)

31. RONCERO, M.IG: Enrichment method for the isolation of auxotrophic mutants of Mucor using the polyene antibiotic $\mathrm{N}$-glycosyl-polifungin. Carlsberg Res. Commun. 49, 685-690 (1984)

32. SCHIPPER, M.A.A.: On Mucor circinelloides, Mucor racemosus and related species. Studies in Mycology 12, 1-40 (1976)

33. SCHIPPER, M.A.A.: On certain species of Mucor with a key to all accepted species. Studies in Mycology 17, 1-52 (1978)

34. SomkUtı, G.A.: Synthesis of cellulase by Mucor pusillus and Mucor miehei. J. Gen. Microbiol. 81, $1-6(1974)$

35. Somkuti, G.A. \& F.J. Babel: Lipase activity of Mucor pusillus. Appl. Microbiol. 16, $617-619$ (1968)

36. SOUTHERN, E.M.: Detection of specific sequences among DNA fragments separated by gel electrophoresis. J. Mol. Biol. 98, 503-517 (1975)

37. Stahl, U., P. Tudzynska, U. KÜCK \& K. EsSER:
Replication and expression of a bacterial-mitochondrial hybrid plasmid in the fungus Podospora anserina. Proc. Natl. Acad. Sci. USA 79, 3641 3645 (1982)

38. Storck, R: Molecular Mycology. In: Molecular Microbiology. J.B.G. Kwapinski ed. John Wiley \& Sons. Chapter 11, p. 438 (1974)

39. Tilburn, J., C. SCazzocchio, G.G. Taylor, J.H. ZABICKY.ZISSMAN, R.A. LOCKINGTON \& R.W. DAVIES: Transformation by integration in Aspergillus nidulans. Gene 26, 205-221 (1983)

40. VAPNEK, D., J.A. Hautala, J.W. Jacobson, N.H. GILES \& S.R. KuSHNER: Expression in Escherichia coli $\mathrm{K}-12$ of the structural gene for catabolic dehydroquinase of Neurospora crassa. Proc. Natl. Acad. Sci. USA 74, 3508-3512 (1977)

41. YeLton, M.M., J.E. HAMER \& W.E. TimberlaKe: Transformation of Aspergillus nidulans by using a $\operatorname{trp} C$ plasmid. Proc. Natl. Acad. Sci. USA 84 , 1470-1474, (1984)

Accepted by: H. KLENow, E. LUND and S.O. ANDERSEN 